\title{
Autophagy through 4EBP1 and AMPK regulates oxidative stress-induced premature senescence in auditory cells
}

\author{
Nana Akagi Tsuchihashi'1,2, Ken Hayashi ${ }^{1,3}$, Katsuaki Dan ${ }^{4}$, Fumiyuki Goto ${ }^{1}$, Yasuyuki \\ Nomura ${ }^{5}$, Masato Fujioka ${ }^{1}$, Sho Kanzaki ${ }^{1}$, Shizuo Komune ${ }^{2}$, Kaoru Ogawa ${ }^{1}$ \\ ${ }^{1}$ Department of Otorhinolaryngology, Head and Neck Surgery, Keio University, School of Medicine, Tokyo 160-8582, Japan \\ ${ }^{2}$ Department of Otorhinolaryngology, Head and Neck Surgery, Kyushu University, School of Medicine, Fukuoka 812-0054, \\ Japan \\ ${ }^{3}$ Department of Otorhinolaryngology, Kamio Memorial Hospital, Tokyo 101-0063, Japan \\ ${ }^{4}$ Collaborative Research Resources, Core Instrumentation Facility, Keio University, Tokyo 160-8582, Japan \\ ${ }^{5}$ Department of Otorhinolaryngology-Head and Neck Surgery, Nihon University, School of Medicine, Tokyo 173-8610, Japan \\ Correspondence to: \\ Kaoru Ogawa, e-mail: ogawak@a5.keio.jp \\ Keywords: premature senescence, autophagy, AMPK, oxidative stress, auditory cell
}

Received: November 17, 2014

Accepted: December 08, 2014

Published: December 30, 2014

\section{ABSTRACT}

The aim of this study was to determine whether autophagy and AMPK contribute to premature senescence in auditory cells. Incubating HEI-OC1 auditory cells with $5 \mathrm{mM} \mathrm{H}_{2} \mathrm{O}_{2}$ for $1 \mathrm{~h}$ induced senescence, as demonstrated by senescence-associated $\beta$-galactosidase (SA- $\beta$-gal) staining. $\mathrm{H}_{2} \mathrm{O}_{2}$ treatment significantly delayed populationdoubling time, leaving cell viability unchanged. Furthermore, the proportion of SA- $\beta$-gal-positive cells significantly increased. Autophagy-related protein expression increased, with Atg7 and LC3-II peaking $6 \mathrm{~h}$ and Lamp2 peaking $24 \mathrm{~h}$ after $\mathrm{H}_{2} \mathrm{O}_{2}$ treatment. The expression of these proteins decreased $48 \mathrm{~h}$ after treatment. Transmission electron microscopy revealed lipofuscin and aggregates within autolysosomes, which accumulated markedly in the cytoplasm of HEI-OC1 cells $48 \mathrm{~h}$ after treatment. Akt and P70S6 phosphorylation markedly decreased after $\mathrm{H}_{2} \mathrm{O}_{2}$ treatment, but 4EBP1 phosphorylation significantly increased $48 \mathrm{~h}$ after treatment. After RNAi-mediated knockdown (KD) of Atg7 and AMPK, $\mathrm{H}_{2} \mathrm{O}_{2}$-treated cells displayed dense SA- $\beta$-gal staining. Also, premature senescence was significantly induced. These suggest that a negative feedback loop may exist between autophagy and AMPK signaling pathways in HEI-OC1 cells. In our model, oxidative stress-induced premature senescence occurred due to impaired autophagy function through 4EBP1 phosphorylation. Our results also indicate that AMPK may regulate premature senescence in auditory cells in an autophagy-dependent and independent manner.

\section{INTRODUCTION}

Aging is a physiological phenomenon that occurs without fail in all eukaryotes. Cellular senescence manifests as stable cell cycle arrest with active metabolism. Cellular senescence could also play a critical role in aging [1].

The study of cellular senescence began in 1961 when Hayflick and Moorhead discovered that human fibroblasts could only divide a finite number of times in culture [2]. This phenomenon, called replicative senescence, was subsequently determined to result from telomere shortening due to repeated chromosome replication and division [3]. Another kind of cellular senescence is stressinduced premature senescence (SIPS), which is early cellular senescence induced by an oncogene [4] or a variety of stressors, such as oxidative stress or chemotherapeutic agents [5]. SIPS occurs irrespective of telomere shortening status. This shows that cellular senescence does not necessarily need to unfold after extended time passage.

Presbycusis or age-related hearing loss (AHL) results as the function of sensory hair cells, spiral ganglion neurons, and stria vascularis cells in the cochlea of the inner ear deteriorates with age $[6,7]$. Hearing loss can also result from premature senescence of auditory cells 
induced by oxidative stress. Oxidative stress induces Bak-dependent mitochondrial apoptosis, which has been demonstrated to be an important mechanism underlying AHL in C57BL/6J mice [8]. How oxidative stress-induced premature senescence specifically affects auditory cellular function remains unclear.

Autophagy is an essential, homeostatic process by which cells break down unnecessary or dysfunctional cellular components. This evolutionarily conserved process is characterized by the formation of double membrane cytosolic vesicles (called autophagosomes), which sequester cytoplasmic content and then fuse with lysosomes [9, 10]. Autophagy enables cells to recycle aggregated proteins and damaged organelles in the cytoplasm that are essential for living cells to recover from stress, such as energy depletion and oxidative and endoplasmic reticulum stress [11-13]. In short, autophagy plays a housekeeping role in cells.

Autophagy dysfunction has been suggested to induce age-related diseases such as Alzheimer's disease [14], cardiomyopathy [15], and hypercholesterolemia [16]. On the other hand, autophagy induction by spermidine or through calorie restriction extends the life span of yeast, flies, worms, mice, and human immune cells [17] [18]. Impairing autophagy through the RNAi-mediated knockdown of autophagy-related genes induces premature senescence in primary human fibroblasts [19], further underscoring the notion that autophagy plays an important role in extending life span. Reducing calorie intake has been shown to delay the progression of AHL [20, 21], but the molecular mechanism underlying oxidative stressinduced autophagy and premature senescence in auditory cells remains unclear.

AMP-activated protein kinase (AMPK) is an evolutionarily conserved energy sensor that controls nutrient sensing and energy homeostasis. AMPK affects many aspects of cellular function, especially cellular senescence [22]. Acute activation of AMPK also prevents $\mathrm{H}_{2} \mathrm{O}_{2}$-induced premature senescence in primary human keratinocytes [23], so AMPK could regulate cellular senescence through oxidative stress. Alternatively, its role in autophagy may affect cellular senescence. AMPK regulates autophagy through two different pathways: one involving mammalian target of rapamycin (mTOR) and the other involving the direct activation of unc51-like kinase 1 (Ulk1) [24]. Mammalian TOR is a key regulator of autophagy and comprises two major components, mTORC1 and mTORC2 [25]. Despite these known functions, AMPK's role in cellular senescence via autophagy remains elusive in auditory cells.

In light of the above findings, we examined the possible roles of autophagy and AMPK in oxidative stress-induced premature senescence in auditory cells. Conditionally immortalized mouse auditory cells, House Ear Institute-Organ of Corti 1 (HEI-OC1) auditory cells [26], were incubated with a low dose of $\mathrm{H}_{2} \mathrm{O}_{2}$, which induces a senescent phenotype [27]. In addition, we examined how autophagy and AMPK impairment affects replicative life span by using RNAi-mediated knockdown of autophagy-related 7 (Atg7), a mediator of autophagosome biogenesis, and AMPK in auditory cells.

\section{RESULTS}

\section{Low dose of $\mathrm{H}_{2} \mathrm{O}_{2}$ induces premature senescence in HEI-OC1 cells}

Premature cellular senescence can be induced by applying $\mathrm{H}_{2} \mathrm{O}_{2}$ in a concentration-dependent manner [27]. To determine whether oxidative stress plays a role in cellular senescence in auditory cells, we treated cultured HEI-OC1 cells with different concentrations of $\mathrm{H}_{2} \mathrm{O}_{2}(2$ $\mathrm{mM}$ or $5 \mathrm{mM}$ for $1 \mathrm{~h}$ ), washed out the $\mathrm{H}_{2} \mathrm{O}_{2}$ with normal culture medium, and then incubated the cells under permissive conditions [26]. The rate of population doubling significantly decreased by 5 days with $5 \mathrm{mM} \mathrm{H}_{2} \mathrm{O}_{2}$, and then by 15 days with $2 \mathrm{mM}$ and $5 \mathrm{mM} \mathrm{H}_{2} \mathrm{O}_{2}$ (Figure $1 \mathrm{~A}$ ). We confirmed that treatment with the $5 \mathrm{mM} \mathrm{H}_{2} \mathrm{O}_{2}$ for $1 \mathrm{~h}$ had no effect on cell viability (Figure $1 \mathrm{~B}$ ), while continuous 5 $\mathrm{mM} \mathrm{H}_{2} \mathrm{O}_{2}$ treatment significantly decreased viability within 3 to $6 \mathrm{~h}$ (data not shown). Since we obtained significant changes in population doubling without affecting cell viability with brief application of $\mathrm{H}_{2} \mathrm{O}_{2}(5 \mathrm{mM}$ for $1 \mathrm{~h})$, we selected the same condition for further experiments.

Senescence-associated beta-galactosidase (SA$\beta$-gal) is the most widely known biomarker of cellular senescence [28]. We examined SA- $\beta$-gal staining in cultured HEI-OC1 cells treated briefly with $\mathrm{H}_{2} \mathrm{O}_{2}$, as described in the Methods (Cell Viability Assay section). Phase contrast microscopy analysis showed that a significantly increased number of SA- $\beta$-gal-positive cells were among the $\mathrm{H}_{2} \mathrm{O}_{2}$-treated cells $(0.00 \pm 0.00 \%$ [control] versus $6.17 \pm 1.13 \%$ [treated]; $n=5, p<0.001$ ) (Figure $1 \mathrm{C}$ and 1D). Cells also exhibited marked morphological changes, including increased cell size and change in organelle shape, which corresponds to some of the characteristics of senescent cells [29-32].

We further performed staining with propidium iodide (PI) in treated and control cells to examine the morphology of nuclei. Figure 1C shows that the nuclei lost their sharp outlines under epifluorescence optics, and there were changes in nuclear morphology reminiscent of chromatin condensation 2 days after $\mathrm{H}_{2} \mathrm{O}_{2}$ treatment [33, 34]. PI staining revealed punctuate DNA foci in one large nucleus. This is characteristic of cellular senescence; these foci are termed senescence-associated heterochromatic foci (SAHF) [35].

To examine whether cell proliferation is attenuated under oxidative stress, we incorporated bromodeoxyuridine (BrdU) into cultured HEI-OC1 cells. BrdU can be incorporated into the newly synthesized DNA of replicating cells during the $\mathrm{S}$ phase of the cell cycle. 
A

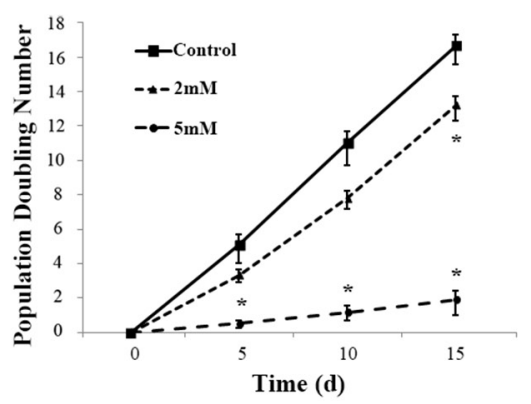

C

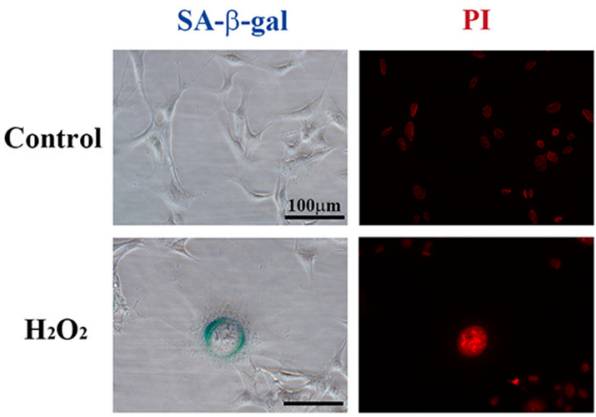

B

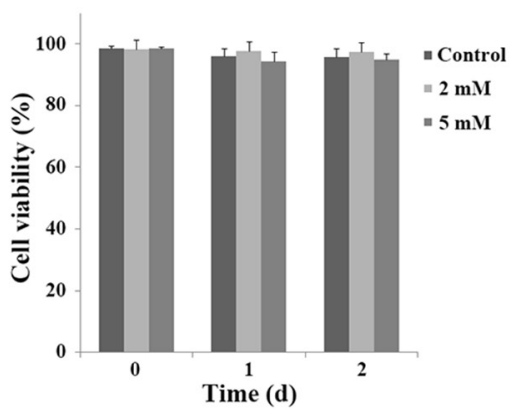

D
E

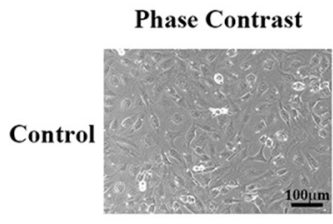

$\mathrm{H}_{2} \mathrm{O}_{2}$

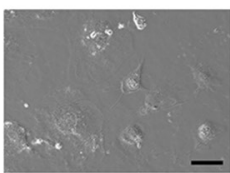

BrdU
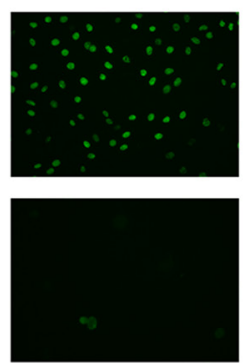

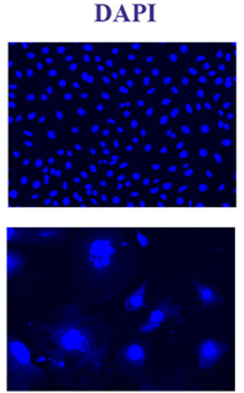

F
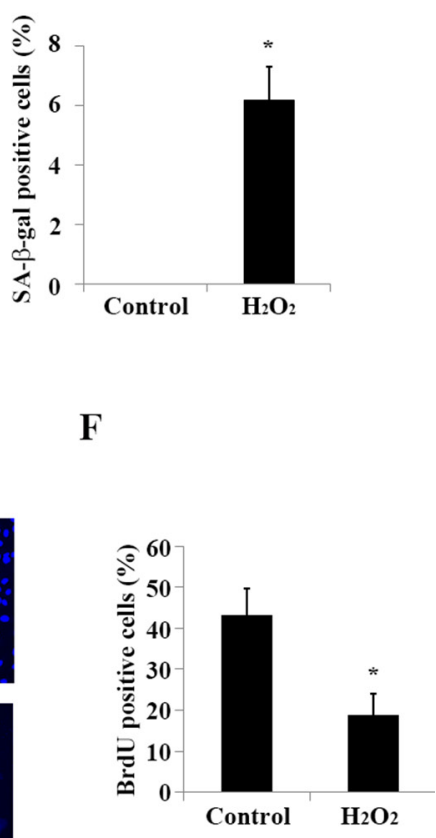

Figure 1: Brief treatment with $\mathrm{H}_{2} \mathrm{O}_{2}$ induces premature senescence in HEI-OC1 cells. (A) Population doubling time. Population doubling experiments were performed in duplicate, as described in the Methods. (B) Cell viability was determined by trypan blue staining at the indicated times after brief $(1 \mathrm{~h})$ treatment with $\mathrm{H}_{2} \mathrm{O}_{2}(2 \mathrm{mM}$ and $5 \mathrm{mM})$. All values are means \pm S.D. from three or more independent studies. ${ }^{*} P<0.05$. (C) Representative senescence-associated $\beta$-galactosidase (SA- $\beta$-gal) staining of HEI-OC1 cells. Propidium iodide (PI) staining labeled nuclear DNA. The assay was carried out in duplicate 2 days after completing the treatment described in the Methods (Cell Viability Assay section). (D) SA- $\beta$-gal-positive cells were quantified by counting more than 100 cells for each sample. All values are means \pm S.D. from three or more independent studies. The control condition exhibited no detectable SA- $\beta$-gal staining; ${ }^{*} P<0.05$. (E) Representative bromodeoxyuridine (BrdU) assay results conducted 2 days after brief treatment with $\mathrm{H}_{2} \mathrm{O}_{2}(5 \mathrm{mM}$ for $1 \mathrm{~h})$. DAPI was used to counterstain DNA in the nucleus for cell identification. (F) BrdU positive HEI-OC1 cells were quantified by counting more than 100 cells for each sample. Values are means \pm S.D. from three or more independent studies. $* P<0.05$.

The proportion of cells incorporating BrdU significantly decreased 2 days after the brief $\mathrm{H}_{2} \mathrm{O}_{2}$ treatment $(43.11$ $\pm 6.5 \%$ [control] versus $18.29 \pm 5.07 \%$ [ $5 \mathrm{mM} \mathrm{H}_{2} \mathrm{O}_{2}$ for $1 \mathrm{~h}], n=5, p<0.001$ ) (Figure $1 \mathrm{E}$ and $1 \mathrm{~F}$ ). These findings indicate that a brief treatment of $\mathrm{H}_{2} \mathrm{O}_{2}$ induces premature senescence in HEI-OC1 cells without leading to cell death.

\section{$\mathrm{H}_{2} \mathrm{O}_{2}$ treatment induces autophagy in HEI-OC1 cells}

Because autophagy plays an important role in mediating cell survival in response to various stressor stimuli, including oxidative stress [36-38], and because it can be regulated by $\mathrm{H}_{2} \mathrm{O}_{2}$ [39], we examined the induction of autophagy in HEI-OC1 cells treated with a low dose of $\mathrm{H}_{2} \mathrm{O}_{2}$. As shown in Figure 2A, Atg7 and macrotubule-associated protein 1 light chain 3-II (LC3II) expression levels significantly increased, peaking $6 \mathrm{~h}$ after $\mathrm{H}_{2} \mathrm{O}_{2}$ treatment, followed by lysosome-associated membrane protein 2 (Lamp2) activation, which peaked at $24 \mathrm{~h}$. However, the expression of these proteins (Atg7, LC3-II, Lamp2) decreased $48 \mathrm{~h}$ after treatment, indicating that, under these brief $\mathrm{H}_{2} \mathrm{O}_{2}$ conditions, autophagy was impaired at $48 \mathrm{~h}$. 

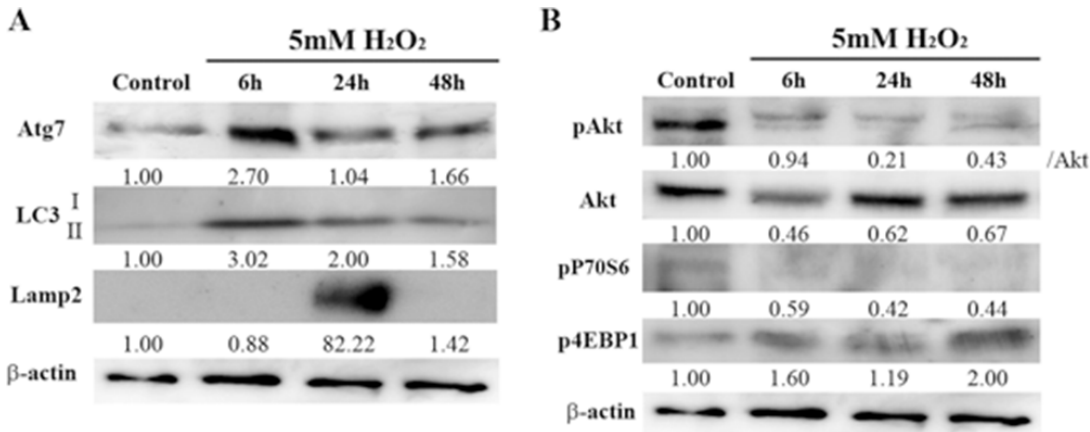

Figure 2: Effects of brief $\mathrm{H}_{2} \mathrm{O}_{2}$ treatment on autophagy signaling pathway in HEI-OC1 cells. (A) Representative Western blots showing the expression of autophagy-related 7 (Atg7), macrotubule-associated protein 1 light chain 3 (LC3), and lysosome-associated membrane protein 2 (Lamp2) in control and $\mathrm{H}_{2} \mathrm{O}_{2}$-treated cells. $\beta$-actin was included as a loading control. The optical density of Atg7, LC3 II, and Lamp2 in $\mathrm{H}_{2} \mathrm{O}_{2}$-treated cells was normalized to that of the corresponding proteins in control cells, and the resulting ratios are indicated below each blot. (B) Western blot analysis of the mammalian target of rapamycin (mTOR) pathway, which negatively regulates autophagy. This pathway includes phosphorylated Akt (pAkt), Akt, pP70S6, and p4EBP1. $\beta$-actin was included as a loading control. The optical density of pAkt, Akt, pP70S6, and p4EBP1 in $\mathrm{H}_{2} \mathrm{O}_{2}$-treated cells were normalized to that of the corresponding proteins in control cells, and the resulting ratios are indicated below each blot.

To elucidate in detail the autophagic pathway induced by the $\mathrm{H}_{2} \mathrm{O}_{2}$ stressor in auditory cells, we further evaluated the mTOR cascade. Mammalian TOR is a multidomain protein kinase that interacts with other proteins to form two main complexes, mTORC1 and mTORC2. Mammalian TORC1 signaling impairs autophagy [9]. Akt is an upstream regulator of mTORC1 and an effector of mTORC2, whereas S6Ks and 4EBPs are downstream substrates of mTORC1 [40]. $\mathrm{H}_{2} \mathrm{O}_{2}$ treatment markedly reduced Akt phosphorylation, but Akt expression remained the same. Phosphorylation of P70S6 kinases (pP70S6) significantly decreased after brief treatment with $\mathrm{H}_{2} \mathrm{O}_{2}$ phosphorylation of 4E-binding protein 1 (p4EBP1) increased $48 \mathrm{~h}$ after treatment (Figure 2B). Taken together, these results support the idea that Akt activity regulates only the phosphorylation of S6K1 but not 4EBP1 in auditory cells.

\section{Ultrastructural changes in the autophagic structures of HEI-OC1 cells treated with a brief, low dose of $\mathrm{H}_{2} \mathrm{O}_{2}$}

We examined ultrastructural autophagic processes in HEI-OCI cells treated with a brief, low dose of $\mathrm{H}_{2} \mathrm{O}_{2}$. Transmission electron microscopy (TEM) revealed that cells in the control condition exhibited normal nuclei with uniform and finely dispersed chromatin. Cytoplasm in these cells also had normal appearing mitochondria (M) and endoplasmic reticulum (ER) (Figure 3A). By contrast, $\mathrm{H}_{2} \mathrm{O}_{2}$-treated cells had accumulated a small number of autophagic vacuoles $6 \mathrm{~h}$ after treatment. At this time, autophagosomes were round, doublemembraned structures, containing electron lucent material and/or dense organelles (Figure 3B). Twentyfour hours after treatment, some autophagosomes were round or oval double-membraned structures, containing the same contents as autophagosomes examined in cells prepared $6 \mathrm{~h}$ after treatment. Other autophagosomes eventually appeared to merge with lysosomes to become autolysosomes containing partially degraded material that appeared as electron dense, unevenly distributed dense masses (Figure 3C1). At this time, autophagosomes and autolysosomes had accumulated to higher concentrations in the treated cells. Figure $3 \mathrm{C} 2$ shows an autophagosome that appeared to form at some ER and became an autolysosome that enveloped damaged mitochondria. Forty-eight hours after treatment, intact lipofuscin and aggregates within autolysosomes accumulated markedly in the cytoplasm [41] (Figure 3D1 and 3D2). These observations support the hypothesis that a briefly applied $\mathrm{H}_{2} \mathrm{O}_{2}$ impairs autophagic processes at the ultrastructural level, appearing as soon as $48 \mathrm{~h}$ after $\mathrm{H}_{2} \mathrm{O}_{2}$ treatment.

\section{Impaired autophagy induces premature senescence in HEI-OC1 cells}

We next examined the relationship between premature senescence and autophagy in HEI-OC1 cells, which were induced by treatment with brief application of $\mathrm{H}_{2} \mathrm{O}_{2}$. When $\operatorname{Atg} 7$ was knocked down by siRNA (Figure $4 \mathrm{~A})$, autophagy was successfully inhibited and LC3 levels were attenuated, as assessed by Western blotting (Figure 4B). Expression of SA- $\beta$-gal was significantly elevated in Atg7-depleted HEI-OC1 cells 2 days after $\mathrm{H}_{2} \mathrm{O}_{2}$ treatment $\left(1.34 \pm 0.19\right.$ [control] versus $2.72 \pm 0.39\left[5 \mathrm{mM} \mathrm{H}_{2} \mathrm{O}_{2}\right.$ for $1 \mathrm{~h}] ; n=3, p<0.02)$, indicating its dependence on autophagy (Figure 4C). These results suggest that impairing autophagy induces premature senescence in auditory cells, as assessed by SA- $\beta$-gal. 


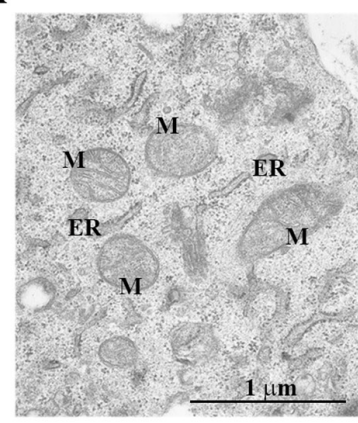

B

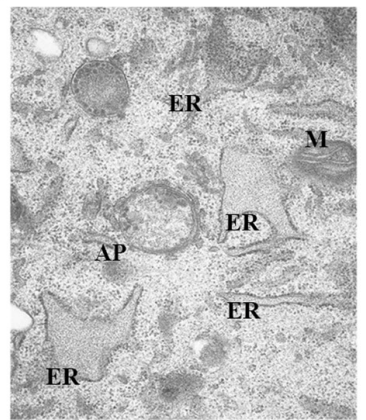

$\mathrm{C} 1$

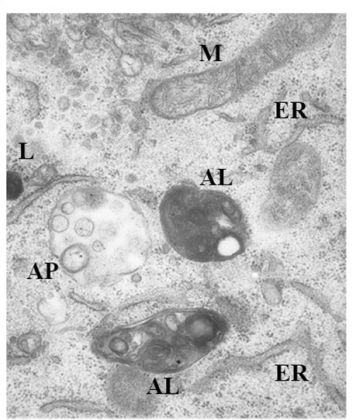

$\mathrm{C} 2$

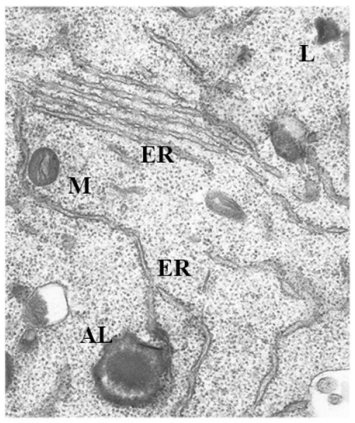

D1

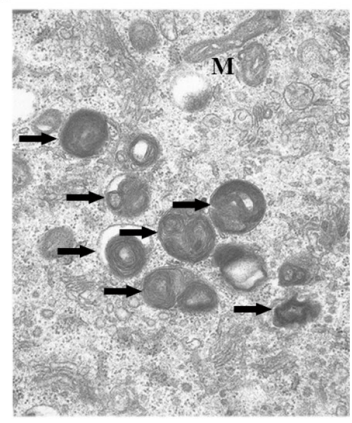

D2

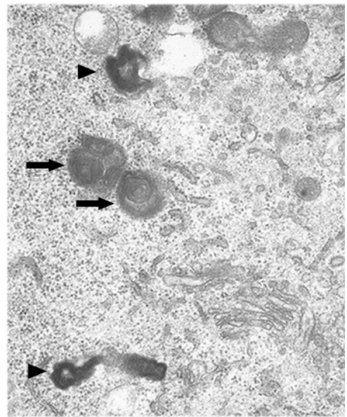

Figure 3: Changes in the ultrastructure of autophagic structures in $\mathrm{HEI}-\mathrm{OC} 1$ cells treated with $\mathrm{H}_{2} \mathrm{O}_{2}$ briefly. Representative transmission electron microscopy (TEM) photomicrographs of HEI-OC1 cells. Cells were treated as in cell viability and population doubling experiments (Methods). (A) Control cell. (B-D) Cells $6 \mathrm{~h}$ (B), $24 \mathrm{~h} \mathrm{(C1,} \mathrm{C2),} \mathrm{and} 48 \mathrm{~h}$ (D1, D2) after treatment with 5 mM $\mathrm{H}_{2} \mathrm{O}_{2}$ for $1 \mathrm{~h}$. AP, autophagosome; AL, autolysosome; M, mitochondria; ER, endoplasmic reticulum; L, lysosome. The arrowheads and arrows point to lipofuscin and aggregates, respectively.

$\mathbf{A}$

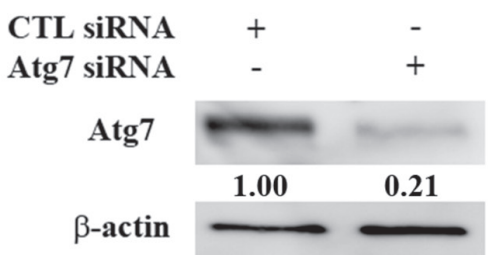

B

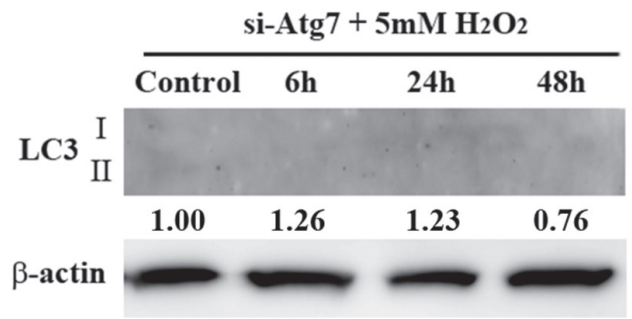

$\mathrm{C}$

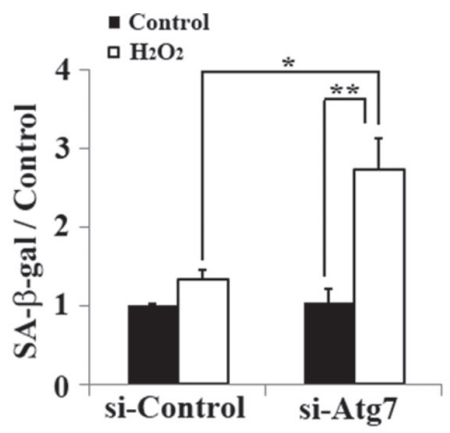

si-Control + $5 \mathrm{mM} \mathrm{H}_{2} \mathrm{O}_{2}$

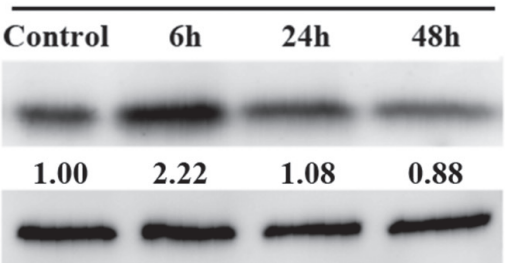

Figure 4: Atg7-knockdown associated autophagy impairment induces premature senescence in HEI-OC1 cells. (A) Western blots of lysates from HEI-OC1 cells knocked down with Atg7 siRNA (see Methods). $\beta$-actin was included as a loading control. (B) Western blots of lysates from $\mathrm{H}_{2} \mathrm{O}_{2}$-treated HEI-OC1 cells. After transfection with Atg7 siRNA for 2 days, cells were treated with $\mathrm{H}_{2} \mathrm{O}_{2}(5 \mathrm{mM}, 1 \mathrm{~h})$, and then cultured for 2 days before harvesting and preparation for Western blotting analyses. $\beta$-actin was included as a loading control. The optical density of LC3 II in $\mathrm{H}_{2} \mathrm{O}_{2}$-treated cells were normalized to that of LC3 II proteins in control cells, and the resulting ratios are indicated below each blot. (C) Quantification of SA- $\beta$-gal staining intensity 2 days after treatment with $5 \mathrm{mM} \mathrm{H}_{2} \mathrm{O}_{2}$ $(1 \mathrm{~h})$ and transfection with control or Atg7 siRNA. Quantitative fluorescence analysis was conducted as described in the Methods. All values are means \pm S.D. from three or more independent studies. $* P<0.05 ; * * P<0.01$. 


\section{AMPK participates in the induction of premature senescence in $\mathrm{HEI}-\mathrm{OC} 1$ cells}

We further examined how AMPK contributes to premature senescence through oxidative stress in auditory cells. In HEI-OC1 cells knocked down with AMPK $\alpha$ siRNA (Figure 5A), SA- $\beta$-gal significantly increased 2 days after $\mathrm{H}_{2} \mathrm{O}_{2}$ treatment $(1.34 \pm 0.12$ [control] versus $\left.2.39 \pm 0.31\left[5 \mathrm{mM} \mathrm{H}_{2} \mathrm{O}_{2}\right] ; n=3, p<0.04\right)$. This indicates that induction of premature senescence in auditory cells depends not only on autophagy impairment but also on AMPK dysfunction (Figure 5B).

\section{A negative feedback loop exists between autophagy and AMPK signaling pathways in HEI-OC1 cells}

To better understand the relationship between autophagy and AMPK in $\mathrm{H}_{2} \mathrm{O}_{2}$-induced premature senescence in HEI-OC1 cells, we assessed AMPK phosphorylation in $\mathrm{H}_{2} \mathrm{O}_{2}$-treated si-control cells and Atg7 knockdown (KD) cells, and LC3 expression in si-control cells and AMPK $\alpha$ KD cells. Figure 6A shows that brief treatment with $\mathrm{H}_{2} \mathrm{O}_{2}$ led to phosphorylation of AMPK in a time-dependent manner. Knockdown of $\operatorname{Atg} 7$ resulted in robust phosphorylation of AMPK, which occurred rapidly $6 \mathrm{~h}$ after $\mathrm{H}_{2} \mathrm{O}_{2}$ treatment (Figure 6B). However, RNAi-mediated knockdown of AMPK $\alpha$ decreased LC3-II expression relative to expression in si-control cells $6 \mathrm{~h}$ after treatment $(5 \mathrm{mM}, 1 \mathrm{~h}$ ) (Figure $6 \mathrm{C} 1,6 \mathrm{C} 2)$. These results support the existence of a negative feedback loop between autophagy and AMPK signaling pathways in auditory cells.

\section{DISCUSSION}

In this study, we demonstrated that oxidative stressinduced premature senescence in auditory cells is regulated by autophagy through 4EBP1 and AMPK. Several lines of evidence support this conclusion. Briefly applied $\mathrm{H}_{2} \mathrm{O}_{2}$ at a low dose $(5 \mathrm{mM}$ for $1 \mathrm{~h}$ ) induced premature senescence in HEI-OC1 auditory cells in vitro. Autophagy was detected $24 \mathrm{~h}$ after the brief $\mathrm{H}_{2} \mathrm{O}_{2}$ treatment and was impaired $48 \mathrm{~h}$ after treatment. During this time, lipofuscin and subcellular aggregates markedly accumulated in the cytoplasm of these cells. Phosphorylation of AKt and P70S6 decreased in a time-dependent manner, while phosphorylation of 4EBP1 increased $48 \mathrm{~h}$ after $\mathrm{H}_{2} \mathrm{O}_{2}$ treatment. Autophagy impairment and AMPK dysfunction led to premature senescence in these auditory cells. Taken together, these findings provide evidence that a negative feedback loop is present in auditory cells that includes autophagy and AMPK signaling pathways.

To establish an auditory cell model of premature senescence, we used low doses of $\mathrm{H}_{2} \mathrm{O}_{2}$ as a stressor to induce premature senescence in HEI-OC1 auditory cells. $\mathrm{H}_{2} \mathrm{O}_{2}$ has been used to induce premature senescence in other cell types as well, such as vascular endothelial cells [42] and keratinocytes [24]. In our system, brief $\mathrm{H}_{2} \mathrm{O}_{2}$ treatment resulted in delayed cell proliferation in the absence of a remarkable decrease in cell viability (Figure $1 \mathrm{~A}$ and $1 \mathrm{~B})$, suggesting that the cells underwent oxidative stress-induced premature senescence. As shown in Figure $1 \mathrm{C}$, the cytoplasm of cells displaying morphological characteristics common to cellular senescence stained intensely for SA- $\beta$-gal, a distinct marker of cellular senescence. By contrast, the proportion of BrdU incorporated into newly synthesized DNA significantly decreased. These results support the use of our system as a model for studying premature senescence in auditory cells. This report is the first to show that SA- $\beta$-gal is useful for staining non-dividing, postmitotic cells like auditory cells.

In this study, we also confirmed that brief application of $\mathrm{H}_{2} \mathrm{O}_{2}$ induced $\mathrm{Atg} 7$ expression, which peaked $6 \mathrm{~h}$ after treatment (Figure 2). This correlated well with the
A

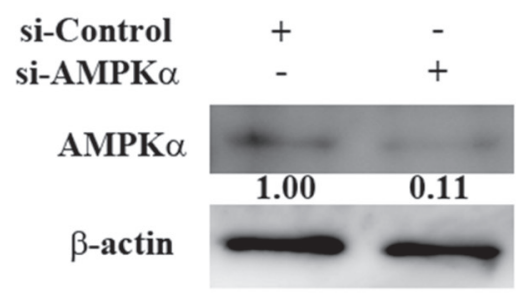

B

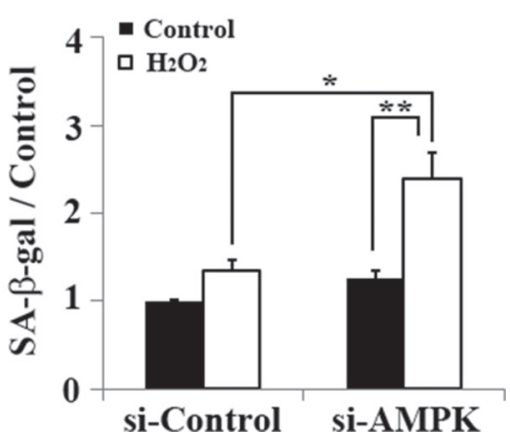

Figure 5: AMPK dysfunction resulting from AMPKa knockdown leads to premature senescence in HEI-OC1 cells. (A) Representative Western blot showing AMPK $\alpha$ expression in HEI-OC1 cells transfected with control or AMPK $\alpha$ siRNA. AMPK $\alpha$ expression levels were determined 2 days after transfection to validate the efficiency of $A M P K \alpha$ knockdown. $\beta$-actin was included as a loading control. The optical density of AMPK $\alpha$ in $\mathrm{H}_{2} \mathrm{O}_{2}$-treated cells was normalized to that of AMPK $\alpha$ in si-control cells, and the resulting ratios are indicated below each blot. (B) Quantification of SA- $\beta$-gal staining intensity 2 days after 1-h treatment with $5 \mathrm{mM} \mathrm{H}_{2} \mathrm{O}_{2}$ and transfection with control siRNA or $A M P K \alpha$ siRNA. Quantitative fluorescence analysis was conducted as described in the Methods. All values are means \pm S.D. from three or more independent studies. ${ }^{*} P<0.05 ; * * P<0.01$. 
A

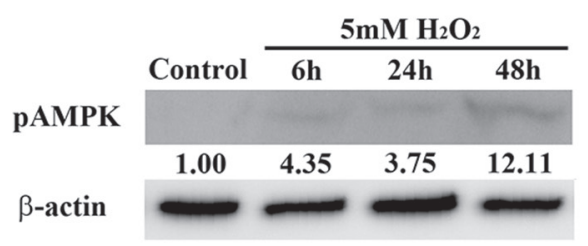

C1

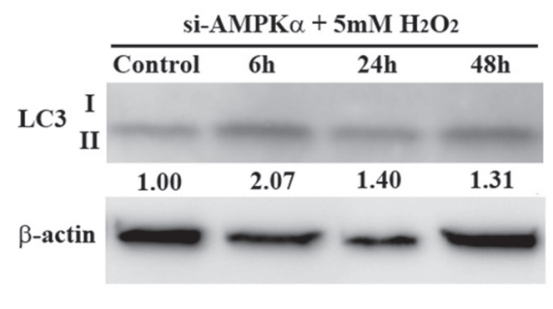

B

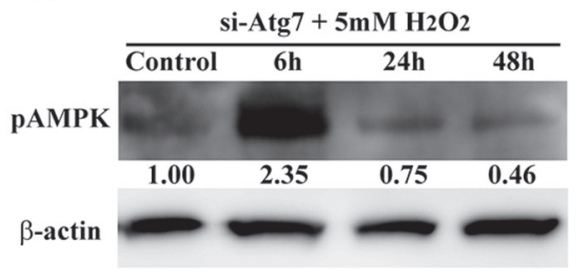

$\mathrm{C2}$

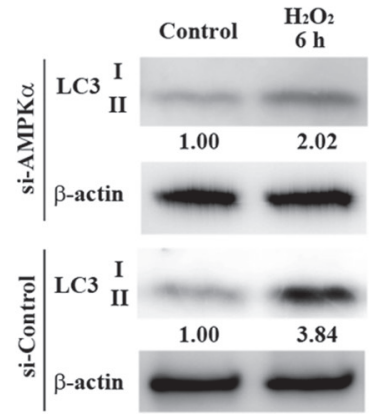

Figure 6: Interaction between autophagy and AMPK signaling pathways in HEI-OC1 cells. (A) Western blot analysis of AMPK phosphorylation (pAMPK) in control cells and $\mathrm{H}_{2} \mathrm{O}_{2}$-treated cells. (B) Representative Western blot showing pAMPK expression at the indicated times after $\mathrm{H}_{2} \mathrm{O}_{2}$ treatment. $\mathrm{HEI}-\mathrm{OC} 1$ cells were transfected with $\operatorname{Atg} 7$ siRNA, treated with $5 \mathrm{mM} \mathrm{H}_{2} \mathrm{O}_{2}$ for $1 \mathrm{~h}$, and then pAMPK expression levels were determined by Western blot 2 days later. $\beta$-actin was included as a loading control. (C1, C2) Western blots of lysates from HEI-OC1 cells transfected with $A M P K \alpha$ siRNA. As above, LC3 expression was assessed after $\mathrm{H}_{2} \mathrm{O}_{2}$ treatment $(5 \mathrm{mM}, 1 \mathrm{~h})$ and 2 days after transfection. $\beta$-actin was included as a loading control. LC3-II expression in $\mathrm{H}_{2} \mathrm{O}_{2}$-treated AMPK $\alpha \mathrm{KD}$ cells was lower than that in si-control cells $6 \mathrm{~h}$ after $\mathrm{H}_{2} \mathrm{O}_{2}$ treatment. For all blots (A-C), the optical density of the indicated proteins in $\mathrm{H}_{2} \mathrm{O}_{2}$-treated cells was normalized to that in control cells; the resulting ratios are indicated below each respective blot. All values are means \pm S.D. from three or more independent studies.

expression of LC3-II in auditory cells (Figure 2). We chose to assess Atg7, a mediator of autophagosomal biogenesis, because it has been demonstrated to be a viable target through which to activate basal autophagic function in another cell type, cardiomyocytes [43]. Moreover, genetic deletion of Atg7 results in an overt loss of autophagy, showing that Atg7 is necessary for processing LC3-I to activate LC3-II and autophagosome formation [44]. Our results suggest that autophagy is induced at an early point in oxidative stress-induced premature senescence, and $\operatorname{Atg} 7$ is important for autophagosome formation in auditory cells and the subsequent induction of cellular senescence.

Lamp2 induction peaked $24 \mathrm{~h}$ after $\mathrm{H}_{2} \mathrm{O}_{2}$ treatment. Lamp2 is required for the proper fusion of lysosomes with autophagosomes in the last stages of the autophagic process [45]. This suggests that in auditory cells, autophagosomes fuse with lysosomes, and then become autolysosomes within $24 \mathrm{~h}$. Interestingly, the expression of Atg7, LC3-II, and Lamp2 decreased $48 \mathrm{~h}$ after induction with $\mathrm{H}_{2} \mathrm{O}_{2}$, indicating that autophagy function had declined by this time. In fact, TEM revealed that a few autophagosomes already exist in the cytoplasm as early as $6 \mathrm{~h}$ after treatment with low doses of $\mathrm{H}_{2} \mathrm{O}_{2}$. The presence of autolysosomes was confirmed $24 \mathrm{~h}$ after treatment.

Also, lipofuscin and subcellular aggregates, which accumulate heavily during aging and appear to affect cellular function [41], increased in number in the cytoplasm $48 \mathrm{~h}$ after $\mathrm{H}_{2} \mathrm{O}_{2}$ treatment in our model system. This clearly indicates that autophagy was induced by $24 \mathrm{~h}$ after $\mathrm{H}_{2} \mathrm{O}_{2}$ treatment and was impaired $48 \mathrm{~h}$ after treatment. It is reasonable to propose that auditory cells progressively became dysfunctional due to the accumulation of lipofuscin and aggregates in the cytoplasm, reaching premature senescence at the 48-h point in our model (Figure 7A).

We confirmed that Akt phosphorylation was significantly decreased in our model. Low levels of Akt phosphorylation are associated with stress-induced senescence in endothelial cells [46]. It is well known that Akt is a key positive regulator of mTORC1, a negative regulator of autophagy. As shown in Figure 2B, P70S6 phosphorylation decreased in proportion to that of Akt in a time-dependent manner, whereas 4EBP1 phosphorylation (p4EBP1) increased independent of the Akt-mTORC1 pathway $48 \mathrm{~h}$ after $\mathrm{H}_{2} \mathrm{O}_{2}$ treatment. These results indicate that Akt activity regulates only S6K1 in auditory cells. Considering that in our model premature senescence was induced $48 \mathrm{~h}$ after $\mathrm{H}_{2} \mathrm{O}_{2}$ treatment resulting in autophagy impairment, the regulation of autophagy depends on 4EBP1. Indeed, a recent study demonstrated a possible mTORC1-independent role for 4EBP1 in the regulation of senescence in another model [47].

Many studies have shown that autophagy activation mediates the extension of life span [18, 48]. Conversely, it has been reported that autophagy impairment induces 
A

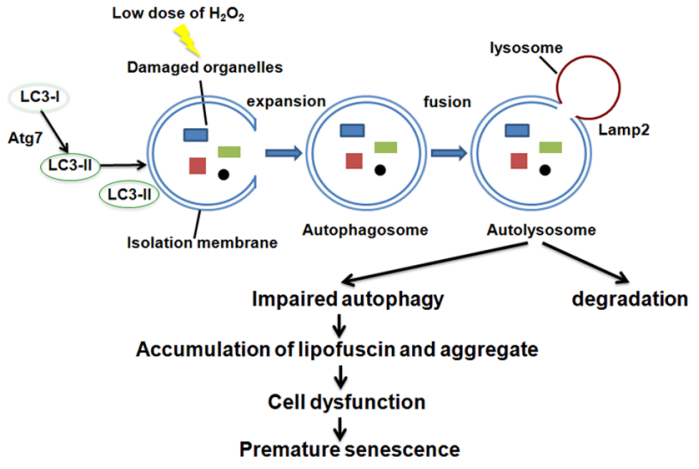

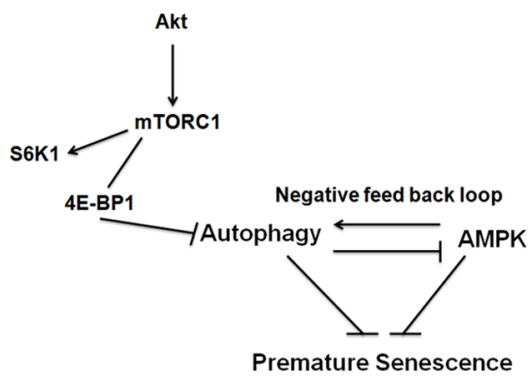

Figure 7: Autophagy and AMPK play important roles in the regulation of oxidative stress-induced premature senescence in auditory cells. Hypothesized schematic model. (A) Autophagy impairment leads to the accumulation of lipofuscin and aggregates in cytoplasm, ultimately resulting in auditory cell dysfunction. Our results indicate that premature senescence was induced in our auditory cellular senescence model. (B) The regulation of autophagy through 4EBP1 phosphorylation plays a key role in oxidative stress-induced premature senescence of auditory cells. In addition, autophagy-dependent and independent involvement of AMPK is pivotal for regulating premature senescence in auditory cells.

premature senescence in primary human fibroblasts [49]. In the present study, RNAi-mediated knockdown of Atg 7 efficiently led to autophagy impairment in auditory cells. There were a significant proportion of senescent cells among $\mathrm{H}_{2} \mathrm{O}_{2}$-treated Atg7 KD cells (Figure 4C). These findings indicate that autophagy impairment due to decreased Atg7 expression may be responsible for premature senescence in auditory cells. To our knowledge, this is the first study to demonstrate that reduction of Atg7 induces premature senescence in auditory cells.

We also investigated the effects of AMPK on $\mathrm{H}_{2} \mathrm{O}_{2}$-induced premature senescence in auditory cells, because AMPK regulates cell survival during stress and coordinates signaling of many age-related transcription factor pathways. A recent study indicates that acute activation of AMPK prevents $\mathrm{H}_{2} \mathrm{O}_{2}$-induced premature senescence in primary human keratinocytes [24]. In our present study, as expected, there was a significantly increased number of densely SA- $\beta$-gal stained senescent cells among the $\mathrm{H}_{2} \mathrm{O}_{2}$-treated Atg7 $\mathrm{KD}$ cells (Figure 5B). AMPK activation upregulates antioxidant mechanisms that diminish $\mathrm{H}_{2} \mathrm{O}_{2}$ [50], while AMPK knockdown increases oxidative stress in 3T3L1 adipocytes [51]. Therefore, the increased number of SA- $\beta$-gal positive cells we observed after AMPK KD could be due to oxidative stress. This suggests that another possible mechanism may exist in auditory cells for AMPK regulation of premature senescence through oxidative stress. Indeed, we observed that AMPK phosphorylation (i.e., AMPK activation) increased in a time-dependent manner, reaching a maximum $48 \mathrm{~h}$ after $\mathrm{H}_{2} \mathrm{O}_{2}$ treatment. This finding indicates that, in turn, AMPK activation upregulates antioxidant mechanisms, since premature senescence was reliably observable in our model $48 \mathrm{~h}$ after brief $\mathrm{H}_{2} \mathrm{O}_{2}$ treatment. Therefore, these apparently conflicting findings indicate that the mechanism in auditory cells - premature senescence regulation through AMPK - could involve regulation of oxidative stress.

AMPK also plays a role as a key activator of the signaling network that maintains cellular housekeeping by autophagy [52, 53]. AMPK usually stimulates autophagy by inhibiting mTOR, but also by directly phosphorylating ULK1 (mammalian homolog of yeast and fly Atg1) [54, 55]. In fact, RNAi-mediated knockdown of $A M P K \alpha$ reduced the expression of LC3II to less than si-control. However, knockdown of Atg7 leads to the early induction of pAMPK $6 \mathrm{~h}$ after treatment. This result indicates AMPK activity could be negatively regulated by Atg7 in auditory cells. Namely, there is a negative feedback loop between autophagy and AMPK pathways in auditory cells (Figure 7B).

In summary, we confirmed that impaired autophagic processes induce oxidative stress-related premature senescence in our auditory cellular premature senescence model. Autophagy was impaired through the phosphorylation of 4EBP1. We also found that autophagy impairment and AMPK dysfunction induced premature senescence in auditory cells. Taken together, these results indicate that AMPK regulates premature senescence in an autophagy-dependent and independent manner. Our results provide significant insights into the role of autophagy (thorough 4EBP1 and AMPK) in oxidative stressinduced premature senescence of auditory cells. To our knowledge, this is the first study to show the association between premature senescence and autophagy in auditory cells. However, further studies need to be conducted to determine how senescence and autophagy affect auditory cellular function and contribute to pathology underlying hearing impairments. 


\section{METHODS}

\section{Regents and antibodies}

Hydrogen peroxide was purchased from Wako (Wako, Osaka, Japan). The following primary antibodies were purchased from Cell signaling Technology (Danvers, MA, USA): anti-Atg7, anti-pP70S6, anti-p4EBP1, antiAMPK $\alpha$, anti-pAMPK $\alpha$. Anti-LC3, anti-Lamp2, and anti- $\beta$-actin antibodies were obtained from Sigma-Aldrich (St. Louis, MO, USA); Santa Cruz Biotechnology, Inc. (Dallas, TX, USA); and BD Biosciences (San Jose, CA, USA), respectively. Anti-mouse and -rabbit HRPlinked secondary antibodies were from GE Healthcare (Buckinghamshire, UK). Small interfering RNA (siRNA) for Atg7, AMPK, and control siRNA were from Cell Signaling Technology. Propidium iodide (PI) solution was also from Cell Signaling Technology. Bromodeoxyuridine (BrdU) and anti-BrdU (Bu20a) antibody were purchased from Cell Signaling Technology. FITC-conjugated secondary antibody was from Life Technologies (Carlsbad, CA, USA).

\section{Cell culture and culture conditions}

HEI-OC1 auditory cells were kindly provided by Dr. D. Lim (House Research Institute, Los Angeles, CA, USA). This conditionally immortalized mouse auditory cell line was established by Kalinec et al. [27], and is a well-established in vitro system for investigating cellular and molecular mechanisms. Cells were maintained in low-glucose Dulbecco's modified medium (DMEM; Wako, Osaka, Japan) supplemented with $10 \%$ fetal bovine serum (FBS; HyClone, UT, USA), 1\% penicillin streptomycin, and $1 \%$ kanamycin (MP Biomedicals, Ohio, USA) at $33^{\circ} \mathrm{C}$ in a humidified incubator with $10 \% \mathrm{CO}_{2}$. This culturing medium also served as the control medium in the population doubling experiments. Maintaining HEI-OC1 cells at this temperature and $\mathrm{CO}_{2}$ concentration is referred to as "permissive conditions" by Kalinec et al. [27], because lower basal apoptotic rates are present.

\section{Transient siRNA transfection}

Small interfering RNA (siRNA) against Atg7 (Sigma-Aldrich), AMPK1/2 (Santa Cruz Biotechnology, Inc.), and control siRNA (Cell Signaling Technology) were used for knockdown of the Atg7 and AMPK1/2 genes. HEI-OC 1 cells were seeded in $25 \mathrm{~cm}^{2}$ flasks and cultured overnight to achieve $90-95 \%$ confluency. Cells were then mechanically scraped from the flasks and transfected with siRNAs using a Gene Pulser electroporation system (BioRad, Hercules, CA, USA), according to the manufacturer's protocol. Two days after transfection, cells were either treated with $\mathrm{H}_{2} \mathrm{O}_{2}$ or remained untreated and then prepared for Western blot analysis (see below).

\section{Cell viability assay}

HEI-OC1 auditory cells $\left(5 \times 10^{4}\right.$ cells $/ \mathrm{ml} /$ well of 24-well plates) were incubated with one of two different concentrations of $\mathrm{H}_{2} \mathrm{O}_{2}(2$ or $5 \mathrm{mM})$, dissolved in the control medium listed in the cell culture and culture condition section for $1 \mathrm{~h}$, and then the $\mathrm{H}_{2} \mathrm{O}_{2}$ solution was replaced with culture medium lacking $\mathrm{H}_{2} \mathrm{O}_{2}$. Control cells were also prepared similarly except without $\mathrm{H}_{2} \mathrm{O}_{2}$. To determine viability, the cells were washed with phosphate-buffered saline (PBS), harvested from the flasks via trypsinization $(0.25 \mathrm{w} / \mathrm{v} \%$ trypsin- $1 \mathrm{mmol} / \mathrm{l}$ EDTA, for $2 \mathrm{~min}$.), resuspended in PBS, and diluted 1:1 in $0.4 \%$ trypan blue solution. Cell viability was calculated with a Countess ${ }^{\circledR}$ Automated Cell Counter (Invitrogen, Life Technologies, USA), following the manufacturer's suggested procedures.

\section{Measurement of population doublings}

To determine the rate of population doublings in HEI-OC1 cells, we used a slightly modified method, as previously described [28]. Cell numbers were counted at the indicated intervals ( 2 or 3 days for control and 2 $\mathrm{mM}-\mathrm{H}_{2} \mathrm{O}_{2}$, and 5 days for $5 \mathrm{mM}-\mathrm{H}_{2} \mathrm{O}_{2}$ group) using a hemocytometer, and then the cells were seeded again in preparation for the next count. The numbers were converted into population doublings according to the following formula: [ $\log$ (No. of cells counted) - $\log$ (No. of cell plated) $] / \log (2)$.

\section{Senescence-associated $\beta$-galactosidase (SA- $\beta$-gal) staining}

SA- $\beta$-gal staining in HEI-OC1 cells was performed using a Senescence Cells Histochemical Staining $\mathrm{Kit}^{\mathbb{\circledR}}$ (Sigma-Aldrich), following the manufacturer's instructions. As above, HEI-OC1 cells were incubated with $5 \mathrm{mM} \mathrm{H}_{2} \mathrm{O}_{2}$ for $1 \mathrm{~h}$, and then the $\mathrm{H}_{2} \mathrm{O}_{2}$ solution was replaced with culture medium lacking $\mathrm{H}_{2} \mathrm{O}_{2}$. Cultured cells were washed with PBS, fixed with Fixative Buffer for 6-7 min, washed again with PBS, and then incubated with the kit's Staining Mixture overnight at $37^{\circ} \mathrm{C}$ in a humidified incubator without the added $10 \% \mathrm{CO}_{2}$ mixture (i.e., $100 \%$ ambient room air). Then undiluted PI solution was added for staining DNA contents in nuclei. Cells were observed with an inverted fluorescence phase-contrast microscope (BioZero BZ-8100 All-In-One Fluorescence Microscope, Keyence, Osaka, Japan). Cells with blue staining in the cytoplasm were scored as positive. To quantify positive staining, more than 100 cells were counted for each sample in duplicate experiments.

Quantitative analysis of fluorescent SA- $\beta$-gal staining was carried out using a 96-well Cellular Senescence Assay Kit ${ }^{\circledR}$ (Cell Biolabs, Inc., San Diego, CA, USA). First, we briefly washed the cells with $1 \times$ PBS and added 
$1 \mathrm{X}$ lysis buffer. After centrifuging the cell lysate for 10 min, the supernatant was collected, and the total protein concentration of each cell lysate sample was determined using a Nanodrop ${ }^{\circledR}$ spectrophotometer (Model \#1000, Nanodrop Technologies, DE, USA). The lysate was mixed with the manufacturer's Assay buffer containing 5\% SA$\beta$-gal solution, and then incubated at $37^{\circ} \mathrm{C}$ protected from ambient room light for $1.5 \mathrm{~h}$. The reaction was stopped by adding the manufacturer's Stop solution. SA- $\beta$-gal fluorescence was detected and measured with a fluorescence plate reader at $360 \mathrm{~nm}$ (excitation wavelength) / $465 \mathrm{~nm}$ (emission wavelength).

\section{BrdU incorporation and detection}

HEI-OC1 cells were seeded onto $35 \mathrm{~mm}$ dishes, and BrdU incorporation was conducted by adding diluted BrdU in warmed culture medium to a final concentration of $0.03 \mathrm{mg} / \mathrm{ml}$ and incubated for $30 \mathrm{~min}$. After aspirating this media, cells were fixed by covering the cell layer with $70 \%$ ethanol for $5 \mathrm{~min}$, thoroughly washed in PBS, and then incubated in $1.5 \mathrm{M} \mathrm{HCl}$ for $30 \mathrm{~min}$. Cells were then incubated in a mixture of 5\% (wt/vol) normal goat serum and $0.3 \%$ Triton $\mathrm{X}-100$ in PBS for $1 \mathrm{~h}$, and then incubated overnight at $4{ }^{\circ} \mathrm{C}$ in anti-BrdU primary antibody (1:1400) diluted in PBS and 1\% BSA. After washing thoroughly in PBS, cells were incubated in FITC-conjugated secondary antibody for $2 \mathrm{~h}$ in the dark and counterstained with 4',6-diamidino-2-phenylindole (DAPI). The cells were washed thoroughly in PBS and observed with an all-in-one epifluorescence microscope (BioZero BZ-8100, Keyence). Cell counts were done at $60 \times$ magnification. Cells with positive nuclear staining were scored as positively incorporating BrdU. To quantify positive staining, more than 100 cells were counted for each sample in duplicate.

\section{Protein extraction and Western blotting}

Western blotting was performed as follows. HEI-OC1 cell samples were trypsinized for $2 \mathrm{~min}$ and homogenized in $20 \mathrm{mM}$ HEPES, containing 1\% Triton $\mathrm{X}-100$. Once homogenized, cell extracts were centrifuged at $10,000 \mathrm{rpm}$ at $4^{\circ} \mathrm{C}$ and supernatants were collected. The protein concentration of the supernatant was evaluated with a Nanodrop ${ }^{\circledR}$ spectrophotometer (Nanodrop Technologies). An equal volume of $2 \times$ SDS sample buffer was added to the samples, and the samples were then boiled for $3 \mathrm{~min}$. Samples $(25 \mu \mathrm{g})$ were subjected to electrophoresis on 10-12.5\% SDS-polyacrylamide gels for 60-80 min at 40mA and then transferred onto PVDF membranes using iBlot $^{\circledR}$ (Invitrogen). The membranes were incubated overnight at $4{ }^{\circ} \mathrm{C}$ in $5 \%(\mathrm{wt} / \mathrm{vol})$ dried milk protein or $2 \%(\mathrm{wt} / \mathrm{vol})$ bovine serum albumin in TBS containing $0.1 \%$ ( vol/vol) Tween-20 (TBS-T), washed in TBS-T, and then incubated overnight at $4{ }^{\circ} \mathrm{C}$ in the presence of primary antibodies (see Reagents and
Antibodies section) at dilutions of 1:200-1:1000 in Can Get Signal ${ }^{\circledR}$ solution (TOYOBO, Japan). After 3 washes with TBS-T, the membranes were incubated with the corresponding species-appropriate secondary antibody at a dilution of 1:5000 in Can Get Signal ${ }^{\circledR}$ solution, and developed with Immunostar (Wako, Osaka, Japan).

\section{Transmission electron microscopy}

HEI-OC1 cells were harvested by trypsinization, and then were fixed with $2 \%$ glutaraldehyde in $0.1 \mathrm{M}$ sodium cacodylate buffer ( $\mathrm{pH} 7.2$ ) for $1 \mathrm{~h}$ followed by $1 \%$ osmium tetroxide in $0.1 \mathrm{M}$ sodium cacodylate buffer $(\mathrm{pH}$ 7.2) for 2 h. To enhance contrast for TEM, samples were en-bloc stained with $0.5 \%$ aqueous uranyl acetate overnight and then dehydrated by alcohols at $4^{\circ} \mathrm{C}$ and infiltrated with a graded series of Epon/Araldite mixture, followed by embedding in $100 \%$ Epon/Araldite. Thin sections $(70 \mathrm{nM})$ were cut with a diamond knife, mounted on EM grids, and stained with Reynolds' lead citrate solution, washed, dried, and imaged using a FEI Tecnai 12 transmission electron microscope (Field Emission Incorporated, Hillsboro, Oregon, U.S.A.).

\section{Statistical analysis}

All data were expressed as means \pm S.D. Statistical analysis was carried out by using one-way analysis of variance and Student's $t$ tests. $P$ values less than 0.05 were considered to indicate statistical significance.

\section{ACKNOWLEDGEMENTS}

We thank Drs. Federico Kalinec (UCLA, Los Angeles, CA, USA) for providing HEI-OC1 auditory cells, Toyoharu Jike (Nihon University, Tokyo, Japan) for technical assistance, and Tomoko Muraki for cell preparation. We acknowledge Grant in aid from the Takeda science foundation (SK).

\section{REFERENCES}

1. Baker DJ, Wijshake T, Tchkonia T, LeBrasseur NK, Childs BG, Sluis B, Kirkland JL, Deursen JM. Clearance of p16Ink4a-positive cells delays ageing-associated disorders. Nature. 2012; 479:232-236.

2. Hayflick L, Moorhead PS. The serial cultivation of human diploid cell strains. Exp Cell Res. 1961; 25:585-621.

3. Yu G, Bradley JD, Attardi LD, Blackburn EH. In vivo alteration of telomere sequences and senescence caused by mutated Tetrahymena telomerase RNAs. Nature. 1990; 344:126-132.

4. Collado M, Blasco MA, Serrano M. Cellular senescence in cancer and aging. Cell. 2007; 130:223-33.

5. Campisi J, d'Adda di Fagagna F. Cellular senescence: when bad things happen to good cells. Nat Rev Mol Cell Biol. 2007; 8:729-40. 
6. Gates G, Mills JH. Presbycusis. Lancet. 2005; 366:1111-20.

7. Yamasoba T, Someya S, Yamada C, Weindruch R, Prolla TA, Tanokura M. Role of mitochondrial dysfunction and mitochondrial DNA mutations in age-related hearing loss. Hear Res. 2007; 226:185-93.

8. Someya S, Xu J, Kondo K, Ding D, Salvi RJ, Yamasoba T, Rabinovitch PS, Weindruch R, Leeuwenburgh C, Tanokura M, Prolla TA. Age-related hearing loss in C57BL/6J mice is mediated by Bak-dependent mitochondrial apoptosis. Proc Natl Acad Sci U S A. 2009; 106:19432-7.

9. Mizushima N, Levine B, Cuervo AM, Klionsky DJ. Autophagy fights disease through cellular self-digestion. Nature. 2009; 451:1069-1075.

10. Ohsumi Y. Molecular dissection of autophagy: two ubiquitin-like systems. Nat Rev Mol Cell Biol. 2001; 2:211-61.

11. Kuma A, Hatano M, Matsui M, Yamamoto A, Nakaya $H$, Yoshimori T, Ohsumi Y, Tokuhisa T, Mizushima N. The role of autophagy during the early neonatal starvation period. Nature. 2004; 432:1032-6.

12. Ichimura Y, Waguri S, Sou YS, Kageyama S, Hasegawa J, Ishimura R, Saito T, Yang Y, Kouno T, Fukutomi T, Hoshii T, Hirao A, Takagi K, et al. Phosphorylation of p62 activates the Keap1-Nrf2 pathway during selective autophagy. Mol Cell. 2013; 51:618-31.

13. Ogata M, Hino S, Saito A, Morikawa K, Kondo S, Kanemoto S, Murakami T, Taniguchi M, Tanii I, Yoshinaga K, Shiosaka S, Hammarback J, Urano F, et al. Autophagy is activated for cell survival after endoplasmic reticulum stress. Mol Cell Biol. 2006; 26:9220-31.

14. Lee JH, Yu WH, Kumar A, Lee S, Mohan PS, PeterhoffCM, Wolfe DM, Martinez-Vicente M, Massey AC, Sovak G, Uchiyama Y, Westaway D, Cuervo AM, et al. Lysosomal proteolysis and autophagy require presenilin 1 and are disrupted by Alzheimer-related PS1 mutations. Cell. 2010; 141:1146-58.

15. Taneike M, Yamaguchi O, Nakai A, Hikoso S, Takeda T, Mizote I, Oka T, Tamai T, Oyabu J, Murakawa T, Nishida K, Shimizu T, Hori M, et al. Inhibition of autophagy in the heart induces age-related cardiomyopathy. Autophagy. 2010; 6:600-6.

16. Stranicro S, Cavallini G, Donati A, Pallottini V, Martini C, Trentalance A, Bergamini E. Stimulation of autophagy by antilipolytic drugs may rescue rodents from age-associated hypercholesterolemia. Rejuvenation Res. 2009; 12:77-84.

17. Eisenberg T, Knauer H, Schauer A, Büttner S, Ruckenstuhl C, Carmona-Gutierrez D, Ring J, Schroeder S, Magnes C, Antonacci L, Fussi H, Deszcz L, Hartl R, et al. Induction of autophagy by spermidine promotes longevity. Nat Cell Biol. 2009; 11:1305-14.

18. Morselli E, Maiuri MC, Markaki M, Büttner S, Ruckenstuhl C, Carmona-Gutierrez D, Ring J, Schroeder S, Magnes C, Antonacci L, Fussi H, Deszcz L, Hartl R, et al. Caloric restriction and resveratrol promote longevity through the Sirtuin-1-dependent induction of autophagy. Cell Death Dis. 2010; 1:e10.

19. Kang HT, Lee KB, Kim SY, Choi HR, Park SC. Autophagy impairment induces premature senescence in primary human fibroblasts. PLoS One. 2011; 6:e23367.

20. Han C, Someya S. Maintaining good hearing: calorie restriction, Sirt3, and glutathione. Exp Gerontol. 2013; 8:1091-5.

21. Someya S, Yu W, Hallows WC, Xu J, Vann JM, Leeuwenburgh C, Tanokura M, Denu JM, Prolla TA. Sirt3 mediates reduction of oxidative damage and prevention of age-related hearing loss under caloric restriction. Cell. 2010; 43:802-12.

22. Wang W, Yang X, López de Silanes I, Carling D, Gorospe M. Increased AMP:ATP ratio and AMP-activated protein kinase activity during cellular senescence linked to reduced HuR function. J Biol Chem. 2003; 278:27016-23.

23. Ido Y, Duranton A, Lan F, Cacicedo JM, Chen TC, Breton L, Ruderman NB. Acute activation of AMPactivated protein kinase prevents $\mathrm{H}_{2} \mathrm{O}_{2}$-induced premature senescence in primary human keratinocytes. PLoS One. 2012; 7:e35092.

24. Roach PJ. AMPK $\rightarrow$ ULK1 $\rightarrow$ autophagy. Mol Cell Biol. 2011; 31:3082-4.

25. Jung CH, Ro S-H, Cao J, Otto NM, Kim D-H. mTOR regulation of autophagy. FEBS Lett. 2010; 584:1287-95.

26. Kalinec GM, Webster P, Lim DJ, Kalinec F. A cochlear cell line as an in vitro system for drug ototoxicity screening. Audiol Neuro-Otology. 2003; 8:177-89.

27. Cao C, Lu S, Kivlin R, Wallin B, Card E, Bagdasarian A, Tamakloe T, Wang WJ, Song X, Chu WM, Kouttab N, $\mathrm{Xu} \mathrm{A}$, Wan Y. SIRT1 confers protection against UVBand $\mathrm{H}_{2} \mathrm{O}_{2}$-induced cell death via modulation of $\mathrm{p} 53$ and JNK in cultured skin keratinocytes. J Cell Mol Med. 2009; 13:3632-43.

28. Young JJ, Patel A, Rai P. Suppression of thioredoxin-1 induces premature senescence in normal human fibroblasts. B Biochem. Biophys. Res. Commun. 2010; 392:363-8.

29. Rodier F, Campisi J. Four faces of cellular senescence. J Cell Biol. 2011; 192:547-556.

30. Campisi J, Andersen JK, Kapahi P, Melov S. Cellular senescence: a link between cancer and age-related degenerative disease? Semin Cancer Biol. 2011; 21:354-359.

31. De Cecco M, Jeyapalan J, Zhao X, Tamamori-Adachi M, Sedivy JM. Nuclear protein accumulation in cellular senescence and organismal aging revealed with a novel singlecell resolution fluorescence microscopy assay. Aging (Albany NY). 2011; 3:955-967.

32. Tchkonia T, Zhu Y, van Deursen J, Campisi J, Kirkland JL. Cellular senescence and the senescent secretory phenotype: therapeutic opportunities. J Clin Invest. 2013; 123:966-72. 
33. Chen F-Q, Hill K, Guan Y-J, Schacht J, Sha S-H. Activation of apoptotic pathways in the absence of cell death in an inner-ear immortomouse cell line. Hear Res. 2012; 284:33-41.

34. El Mouedden M, Laurent G, Mingeot-Leclercq MP, Tulkens PM. Gentamicin-induced apoptosis in renal cell lines and embryonic rat fibroblasts. Toxicol Sci. 2000; 56:229-39.

35. Narita M, Nunez S, Heard E, Narita M, Lin AW, Hearn SA, Spector DL, Hannon GJ, Lowe SW. Rb-Mediated Heterochromatin Formation and Silencing of E2F Target Genes during Cellular Senescence. Cell. 2003; 113:703-716.

36. Singh K, Matsuyama S, Drazba JA, Almasan A. Autophagydependent senescence in response to DNA damage and chronic apoptotic stress. Autophagy. 2012; 8:236-251.

37. Shintani T, Klionsky DJ. Autophagy in health and disease: a double-edged sword. Science. 2004; 306:990-995.

38. Kraft C, Peter M, Hofmann K. Selective autophagy: ubiquitinmediated recognition and beyond. Nat Cell Biol. 2010; 12:836-41.

39. Scherz-Shouval R, Shvets E, Fass E, Shorer H, Gil L, Elazar Z. Reactive oxygen species are essential for autophagy and specifically regulate the activity of Atg4. EMBO J. 2007; 26:1749-60.

40. Hands SL, Proud CG, Wyttenbach A. mTOR's role in ageing: protein synthesis or autophagy? Aging (Albany NY). 2009; 1:586-597.

41. Nowotny K, Jung T, Grune T, Höhn A. Accumulation of modified proteins and aggregate formation in aging. Exp Gerontol. 2014; 57C:122-131.

42. Luo Y, Zou P, Zou J, Wang J, Zhou D, Liu L. Autophagy regulates ROS-induced cellular senescence via p21 in a p38 MAPK $\alpha$ dependent manner. Exp Gerontol. 2012; 46:860-867.

43. Pattison JS, Osinska H, Robbins J. Atg7 induces basal autophagy and rescues autophagic deficiency in CryABR120G cardiomyocytes. Circ Res. 2011; 109:151-60.

44. Komatsu M, Waguri S, Ueno T, Iwata J, Murata S, Tanida I, Ezaki J, Mizushima N, Ohsumi Y, Uchiyama Y, Kominami E, Tanaka K, Chiba T. Impairment of starvationinduced and constitutive autophagy in Atg7-deficient mice. J Cell Biol. 2005; 169:425-34.
45. Eskelinen E, Illert A. Role of LAMP-2 in lysosome biogenesis and autophagy. Mol Biol. 2002; 13:3355-3368.

46. Courtois-Cox S, Genther Williams SM, Reczek EE, Johnson BW, McGillicuddy L, Johannessen CM, Hollstein PE, MacCollin M, Cichowski K. A negative feedback signaling network underlies oncogene-induced senescence. Cancer Cell. 2006; 10:459-72.

47. Chao SK, Lin J, Brouwer-Visser J, Smith AB, Horwitz SB, McDaid HM. Resistance to discodermolide, a microtubule-stabilizing agent and senescence inducer, is 4E-BP1dependent. Proc Natl Acad Sci U S A. 2011; 108:391-6.

48. Jia K, Levine B. Autophagy is Required for Dietary Restriction-Mediated Life Span Extension in C. elegans. Autophagy. 2007; 3:6:597-599.

49. Kang HT, Lee KB, Kim SY, Choi HR, Park SC. Autophagy impairment induces premature senescence in primary human fibroblasts. PLoS One. 2011; 6:e23367.

50. Colombo SL, Moncada S. AMPKalpha1 regulates the antioxidant status of vascular endothelial cells. Biochem J. 2009; 421:163-9.

51. Gauthier M-S, O'Brien EL, Bigornia S, Mott M, Cacicedo JM, Xu XJ, Gokce N, Apovian C, Ruderman N. Decreased AMP-activated protein kinase activity is associated with increased inflammation in visceral adipose tissue and with whole-body insulin resistance in morbidly obese humans. Biochem Biophys Res Commun. 2011; 404:382-7.

52. Sengupta A, Molkentin JD, Yutzey KE. FoxO transcription factors promote autophagy in cardiomyocytes. J Biol Chem. 2009; 284:28319-31.

53. Zhao J, Brault JJ, Schild A, Cao P, Sandri M, Schiaffino S, Lecker SH, Goldberg AL. FoxO3 coordinately activates protein degradation by the autophagic/lysosomal and proteasomal pathways in atrophying muscle cells. Cell Metab. 2007; 6:472-83.

54. Kim J, Kundu M, Viollet B, Guan KL. AMPK and mTOR regulate autophagy through direct phosphorylation of Ulk1. Nat Cell Biol. 2011; 13:132-41.

55. Egan DF, Shackelford DB, Mihaylova MM, Gelino S, Kohnz RA, Mair W, Vasquez DS, Joshi A, Gwinn DM, Taylor R, Asara JM, Fitzpatrick J, Dillin A, Viollet B, Kundu M, Hansen M, Shaw RJ. Phosphorylation of ULK1 (hATG1) by AMP-activated protein kinase connects energy sensing to mitophagy. Science. 2011; 331:456-61. 